\title{
THE EFFECTS OF HCG, INDOMETHACIN, FLUFENAMIC ACID AND ASPIRIN IN THE IMMATURE FEMALE RAT
}

\author{
J. M. SHAEFER AND J. WEIDENFELD \\ Department of Endocrinology, Hebrew University-Hadassah Medical School, \\ ferusalem, Israel
}

(Received 30th December 1974)

\begin{abstract}
Summary. Immature female rats ( 21 to 23 days old, 35 to $45 \mathrm{~g}$ ) were injected subcutaneously with 2.5 i.u. HCG $18 \mathrm{hr}$ before autopsy. Ovaries and uteri were removed; wet weight, dry weight and uterine protein content were determined. Ovarian and uterine weights, ovarian blood volume and uterine protein content were increased after HCG treatment. When immature female rats were pretreated with indomethacin, flufenamic acid or aspirin, the ovarian effects of HCG were inhibited: only slight increases in ovarian weight and blood volume were observed. Indomethacin attenuated the increases in uterine weight, and protein content, but neither flufenamic acid nor aspirin were effective in inhibiting these responses. The possible role of prostaglandins and of oestrogen as mediators of these responses is discussed.
\end{abstract}

\section{INTRODUCTION}

Administration of HCG initiates and supports a number of responses in the prepubertal female rat. These responses include: (a) the induction of ovulation (Zondek \& Aschheim, 1927), (b) an increase in ovarian weight (Zondek, 1926), (c) an increase in uterine weight (Siddall, 1928), and (d) the production of an ovarian hyperaemia (Zondek et al., 1945).

Ovarian hyperaemia is the earliest response, occurring in 2 to $18 \mathrm{hr}$ and the enhanced blood flow presumably facilitates and underlies the ensuing events. Histamine has been implicated as a factor mediating the hyperaemia (Szego \& Gitin, 1964). The large doses of antihistamine necessary to block the hyperaemia and the observation that hyperaemia can still be elicited by HCG in ovaries chronically depleted of histamine (Lipner, 1971) suggest, however, that histamine may not be an obligatory factor.

Since prostaglandins also modify blood flow in most vascular beds, including the ovary (Pharriss, 1971), as well as modify ovarian metabolism (Lamprecht et al., 1973), steroidogenesis (Behrman et al., 1971), and ovulation (Tsafriri et al., 1972), we have examined the effects of several inhibitors of prostaglandin synthesis on the ovarian hyperaemia after HCG treatment, and also the uterine 
response to HCG administration during the early phase of HCG action and its modification by the inhibitors.

\section{MATERIALS AND METHODS}

Female rats, 21 days of age, of the Hebrew University strain were used; they were given free access to food and water. In all experiments, the animals were treated orally with $2.5 \mathrm{mg}$ indomethacin (1-(p-chlorobenzoyl)-5-methoxy-2methylindole-3-acetic acid) $/ \mathrm{kg}, 5 \mathrm{mg}$ flufenamic acid ( $\mathrm{N}(\alpha, \alpha, \alpha$ trifluoro-m-tolyl)anthranilic acid) $/ \mathrm{kg}$, or $25 \mathrm{mg}$ aspirin (acetylsalicylic acid) $/ \mathrm{kg}$ at 16.00 hours on Day $21,10.00$ and 16.00 hours on Day 22 and at 08.00 hours on Day 23. Control rats were fed the suspending vehicle $(10 \%$ ethanol in propylene glycol) at the same times. Some of the rats in all treatment groups and the control group were given a subcutaneous injection of 2.5 i.u. HCG (Pregnyl: Organon) in saline at 16.00 hours on Day 22.

Ovarian blood volume (Exps 1 and 2) was determined by the distribution of ${ }^{51} \mathrm{Cr}$-labelled red cells, which were treated according to the procedure of Sterling (1960) with $10 \mu \mathrm{Ci}{ }^{51} \mathrm{Cr}$ (Radiochemical Centre, Amersham)/ml whole rat blood. Each animal received an injection into the tail vein of $0.5 \mathrm{ml}$ blood with labelled red cells at 12.00 hours on Day 23 and was killed $1 \mathrm{hr}$ later by an overdose of ether. The ovaries were removed, trimmed and an aliquot of venous blood was taken. Radioactivity was counted in a Packard "Autogamma' Scintillation Spectrometer set for peak ${ }^{51} \mathrm{Cr}$ efficiency. The blood volume was calculated as the ratio of $\mathrm{ct} / \mathrm{min}$ per pair of ovaries:ct/min per $\mu \mathrm{l}$ blood.

In Exps 3, 4, 5, 6 and 7, rats were given an overdose of ether at 11.00 hours on Day 23. The ovaries and uteri were removed, trimmed and weighed to the nearest 0.1 or $0.01 \mathrm{mg}$ on a torsion balance (wet weights) or in tared vessels on an electronic balance (dry weights). Dry weights were measured the following morning after heating the samples in an oven at $80^{\circ} \mathrm{C}$ overnight. Protein was determined according to the procedure of Lowry et al. (1951).

Statistical calculations (analysis of variance) were performed with Dunnett's (1955) procedure for comparing several means to a single control or Tukey's (1949) method for testing all possible comparisons.

\section{RESULTS}

Ovary

Treatment with HCG elicited a marked rise in ovarian blood volume (Table 1). Treatment of the rats with indomethacin, flufenamic acid or aspirin resulted in an inhibition of this rise. There was a small decrease in ovarian blood volume in the rats treated with these drugs that was particularly noticeable after the treatment with indomethacin (Exp. 1), but the reduction was not statistically significant at the $5 \%$ level. At autopsy, the ovaries of the indomethacin-treated animals appeared pale and white, whereas blood vessels were always visible on the surface of ovaries from control rats and were par- 
Table 1. The effects of HCG and three prostaglandin inhibitors on the ovarian blood content of immature rats

\begin{tabular}{lrl}
\hline \multicolumn{1}{c}{ Treatment } & $\begin{array}{c}\text { No. of } \\
\text { rats }\end{array}$ & $\begin{array}{c}\text { Ovarian blood content } \\
(\mu l \text { pair ovaries })\end{array}$ \\
\hline Experiment 1 & & \\
$\quad$ None (control) & 11 & $0 \cdot 368 \pm 0.047$ \\
HCG & 14 & $0 \cdot 557 \pm 0 \cdot 051^{*}$ \\
HCG +indomethacin & 8 & $0 \cdot 302 \pm 0 \cdot 047$ \\
$\quad$ Indomethacin & 9 & $0 \cdot 245 \pm 0 \cdot 026$ \\
Experiment 2 & & \\
$\quad$ None (control) & 5 & $0 \cdot 392 \pm 0 \cdot 040$ \\
HCG & 6 & $0 \cdot 693 \pm 0 \cdot 060^{* *}$ \\
Flufenamic acid & 5 & $0 \cdot 300 \pm 0 \cdot 030$ \\
Flufenamic acid + HCG & 5 & $0 \cdot 410 \pm 0 \cdot 030$ \\
Aspirin & 6 & $0 \cdot 328 \pm 0 \cdot 030$ \\
Aspirin + HCG & 6 & $0 \cdot 350 \pm 0 \cdot 010$ \\
\hline
\end{tabular}

Values are Means \pm 1 S.E.M.

* Significantly different from control, $P<0.05$.

** Significantly different from control, $P<0.01$.

ticularly prominent on the surface of ovaries from the animals treated with HCG.

In rats given HCG, the ovaries were visibly and measurably heavier by $18 \mathrm{hr}$ after injection (Table 2). The effect of HCG was attenuated by the three inhibitors, which alone did not cause any substantial change in ovarian weight (Table 2).

\section{Uterus}

The effects of HCG and the various inhibitors on uterine weight are shown in Tables 3 and 4.

Table 2. The effect of HCG and three prostaglandin inhibitors on the ovarian weight of immature rats

\begin{tabular}{|c|c|c|c|c|}
\hline Treatment & $\begin{array}{l}\text { No. of } \\
\text { rats }\end{array}$ & $\begin{array}{l}\text { Ovarian wet wt } \\
\quad \text { (mg/pair) }\end{array}$ & $\begin{array}{l}\text { No. of } \\
\text { rats }\end{array}$ & $\begin{array}{l}\text { Ovarian dry wt } \\
(\text { mg/pair })\end{array}$ \\
\hline $\begin{array}{l}\text { Experiment } 3 \\
\text { None (control) } \\
\text { HCG } \\
\text { HCG + indomethacin } \\
\text { Indomethacin }\end{array}$ & $\begin{array}{l}15 \\
12 \\
11 \\
11\end{array}$ & $\begin{array}{l}15 \cdot 50 \\
20 \cdot 50 \\
18 \cdot 80 \\
16 \cdot 60\end{array}$ & $\begin{array}{l}11 \\
10 \\
11 \\
11\end{array}$ & $\begin{array}{l}3 \cdot 03 \\
4 \cdot 40 \\
3 \cdot 50 \\
3 \cdot 30\end{array}$ \\
\hline $\begin{array}{l}\text { Experiment } 4 \\
\text { None (control) } \\
\text { HCG } \\
\text { Flufenamic acid } \\
\text { HCG + flufenamic acid } \\
\text { Aspirin } \\
\text { HCG + aspirin }\end{array}$ & & & $\begin{array}{r}6 \\
12 \\
12 \\
7 \\
6 \\
7\end{array}$ & $\begin{array}{l}2 \cdot 54 \pm 0.21 \\
4 \cdot 48 \pm 0.25 * \\
2 \cdot 77 \pm 0 \cdot 16 \\
3.42 \pm 0 \cdot 29 \\
2 \cdot 33 \pm 0 \cdot 18 \\
3 \cdot 26 \pm 0.15\end{array}$ \\
\hline
\end{tabular}

For Exp. 3, the values are averages derived from pooled weights. For Exp. 4, values are Means \pm 1 S.E.M.

* Value is significantly different by Tukey's procedure from those for the Control, $\mathrm{HCG}+$ flufenamic acid and HCG + aspirin groups, $P<0 \cdot 05$. 
Table 3. Effect of HCG and indomethacin on the uterine weight and protein content of immature rats

\begin{tabular}{llll}
\hline \multicolumn{1}{c}{ Treatment } & \multicolumn{1}{c}{$\begin{array}{c}\text { Wet wt of } \\
\text { uterus } \\
(\mathrm{mg})\end{array}$} & $\begin{array}{c}\text { Dry wt of } \\
\text { uterus } \\
(\mathrm{mg})\end{array}$ & $\begin{array}{c}\text { Protein/uterus } \\
(\mathrm{mg})\end{array}$ \\
\hline Experiment 5 & & & \\
$\quad$ None (control) & $24 \cdot 96 \pm 1 \cdot 26(26)$ & $5 \cdot 07 \pm 0 \cdot 37(16)$ & $2 \cdot 40 \pm 0 \cdot 40(11)$ \\
HCG & $38 \cdot 49 \pm 1.25 * *(30)$ & $7 \cdot 19 \pm 0.36(11)$ & $4 \cdot 61 \pm 0 \cdot 28(11)$ \\
HCG +indomethacin & $29 \cdot 01 \pm 1 \cdot 08(29)$ & $5 \cdot 60 \pm 0.30(16)$ & $2 \cdot 88 \pm 0 \cdot 18(11)$ \\
Indomethacin & $22.69 \pm 0.59(30)$ & $5 \cdot 56 \pm 0.31(16)$ & $2 \cdot 38 \pm 0.08(11)$ \\
\hline
\end{tabular}

Values are Means \pm 1 S.E.M. Figures in parentheses represent the number of uteri. ** $P<0.01$ compared with control.

Table 4. The effect of HCG, flufenamic acid and aspirin on the uterine wet weight of immature rats

\begin{tabular}{lcc}
\hline \multicolumn{1}{c}{ Treatment } & $\begin{array}{c}\text { No. of } \\
\text { tteri }\end{array}$ & $\begin{array}{c}\text { Uterine wet wt } \\
\text { (mg/uterus) }\end{array}$ \\
\hline Experiment 6 & & \\
$\quad$ None (control) & 20 & $21 \cdot 9 \pm 0 \cdot 7$ \\
HCG & 23 & $26.5 \pm 0 \cdot 8^{* *}$ \\
HCG +flufenamic acid & 22 & $27.3 \pm 0.9 * *$ \\
$\quad$ Flufenamic acid & 17 & $22 \cdot 9 \pm 0.8$ \\
Experiment 7 & & \\
$\quad$ None (control) & 6 & $19 \cdot 3 \pm 0 \cdot 8$ \\
HCG & 5 & $34 \cdot 6 \pm 2 \cdot 5^{* *}$ \\
HCG +aspirin & 6 & $36.7 \pm 2 \cdot 2^{* *}$ \\
Aspirin & 6 & $20.2 \pm 1 \cdot 3$ \\
\hline
\end{tabular}

Values are Means \pm 1 S.E.M.

** $P<0.01$ compared with control.

In Exp. 5, there was a 54\% increase in uterine wet weight $18 \mathrm{hr}$ after HCG administration. The increase in wet weight was associated with comparable increases in dry weight and protein content and all these increases were inhibited when indomethacin was also given. For each parameter there was a small rise of 10 to $20 \%$ above control values but the increases were neither statistically significant nor of the same magnitude as those seen in the HCGtreated rats. Indomethacin by itself produced no discernible effect on uterine weight or protein content.

In Exps 6 and 7, neither flufenamic acid nor aspirin was effective in antagonizing the increase in uterine weight elicited by HCG (Table 4).

\section{DISCUSSION}

The factors mediating the ovarian weight gain and hyperaemia are only partly known. In hypophysectomized immature female rats, HCG produces a limited increase in ovarian weight which is confined to the ovarian interstitial tissue (Uma Bai et al., 1973). In intact immature female rats the increase in ovarian weight produced by HCG appears to be due to a synergism with endogenous 
FSH, the secretion of which may be stimulated by HCG (Evans \& Simpson, 1950). The observation that the increase in ovarian weight that occurs in response to HCG was inhibited by indomethacin, flufenamic acid and aspirin suggests that at least part of the overall effect of these agents may be due to an inhibition of gonadotrophin release. Carlson et al. (1974) have found that indomethacin effectively blocks the release of LH in response to oestradiol infusion in the sheep.

Histamine has been implicated as a mediator of ovarian hyperaemia since (a) there is a marked depletion of ovarian histamine 2 to $2 \frac{1}{2} \mathrm{hr}$ after the administration of LH to 21- to 22-day-old female rats (Szego \& Gitin, 1964), and (b) benadryl ( $4 \mathrm{mg} / \mathrm{kg}$ ) blocks the hyperaemia produced by HCG (Lipner, 1971). In contrast, HCG will still elicit hyperaemia in ovaries chronically depleted of histamine by compound 48/80 (a mixture of polymers of p-methoxyn-methylphenylethylamine) (Lipner, 1971). Since prostaglandins have been shown to modify circulatory dynamics in a number of vascular beds (Bergström et al., 1968; Weeks, 1972) and to stimulate several ovarian metabolic processes in vitro (Lamprecht et al., 1973; Ahrén \& Perklev, 1973), it appears reasonable to suggest that they are involved in the production of the ovarian hyperaemia. It is well established that indomethacin, aspirin and flufenamic acid all inhibit the synthesis of prostaglandins (Vane, 1971; Zor et al., 1973), although they may have other actions as well. Each of these inhibitors blocked the increase in ovarian blood content in the rats treated with HCG in the present study, and it is likely that the prostaglandins are involved in the production of the ovarian hyperaemia. Direct confirmation of their role, however, remains to be determined.

The factor(s) mediating the increase in uterine weight seen in these experiments are not immediately obvious. It is evident that a uterotrophic agent is elaborated in the prepubertal female rat since there is a steady increase in uterine weight and histological differentiation from 21 to 42 days of age (Lunn \& Lorraine, 1973; Somjen et al., 1973). It has been shown that there are significant levels of circulating oestrogens in the immature female, although their origin is unclear (Weisz \& Gunsalus, 1973). Thus, the increase in uterine weight elicited by HCG may be secondary to an enhanced secretion of oestrogen.

It is exceedingly difficult, however, to show the presence or synthesis of oestrogen in the prepubertal rat ovary either before or within $24 \mathrm{hr}$ of the administration of HCG (Zondek \& Sulman, 1945; Cierciorowska \& Russfield, 1968). For example, Zondek \& Sulman (1945), by castrating or administering anti-HCG serum to immature rats at specific times following HCG treatment, have shown that evidence can be obtained for the secretion of oestrogen only after 27 to $28 \mathrm{hr}$ of exposure to HCG. In addition, the ovarian conversion of precursors to oestrogen in vitro is very low in the prepubertal rat (Villee et al., 1969; Quattropani \& Weisz, 1973). Thus, the mediation of oestrogen in the responses reported here, which occur by $18 \mathrm{hr}$ after HCG administration, remains undecided.

The site and mode of action of indomethacin in inhibiting the uterine weight increase produced by HCG remains unclear. Its action is probably not related to an inhibition of prostaglandin synthesis since neither flufenamic acid nor 
aspirin duplicated this effect. It may, however, be related to a more general adverse effect of this drug in the rat, such as we have noted on the ovaries, and would dictate that caution be used in interpreting results with this drug.

\section{ACKNOWLEDGMENTS}

We wish to thank Professor M. Finkelstein for his encouragement and advice in carrying on these studies and for his aid in preparing the manuscript. We also wish to thank Mr D. Nussbaum for his excellent technical assistance, Assia Pharmaceuticals Ltd, Tel Aviv, and Raffia Laboratories, Jerusalem, for generously providing the indomethacin, flufenamic acid and aspirin used in these studies, and Dr C. Hershko, Department of Hematology, Hadassah Hospital, for suggesting the ${ }^{51} \mathrm{Cr}$-labelling technique and demonstrating its use.

\section{REFERENCES}

Ahrén, K. \& Perklev, T. (1973) Effects of PGE, and 7-oxy-13-prostynoic acid on the isolated prepubertal rat ovary. Adv. Biosci. 9, 717-721.

Behrman, H., Yoshinaga, K. \& Greep, R.O. (1971) Extraluteal effects of prostaglandins. Ann. N.Y. Acad. Sci. 180, 426-435.

Bergström, S., Garlson, L.A. \& Weeks, J.R. (1968) The prostaglandins: a family of biologically active lipids. Pharmac. Rev. 20, 1-48.

Carlson, J.G., Barcikowskr, B., Gargill, V. \& McCracken, J.A. (1974) The blockade of LH release by indomethacin. F. clin. Endocr. Metab. 39, 399-402.

Cierciorowska, A. \& Russfield, A.B. (1968) Determination of estrogenic activity of the immature rat ovary. Archs Path. 85, 658-662.

Dunnetr, C.W. (1955) A multiple comparison proceedure for comparing several treatments with a control. F. Am. statist. Ass. 50, 1096-1121.

Evans, H.M. \& Simpson, M.E. (1950) Physiology of the gonadotrophins. In The Hormones, Vol. II, pp. 351-404. Eds. G. Pincus and K. V. Thermann. Academic Press, New York.

LAMPRECHT, S.A., ZOR, U., TSAFriri, A. \& Lindner, H.R. (1973) Action of prostaglandin $\mathrm{E}_{2}$ and of luteinizing hormone on ovarian adenylate cyclase, protein kinase and ornithine decarboxylase activity during postnatal development and maturity in the rat. F. Endocr. 57, 217-233.

Lipner, H. (1971) Ovulation from histamine depleted ovaries. Proc. Soc. exp. Biol. Med. 136, 111-114.

Lowry, O.H., Rosebrough, N.S., FarR, A.L. \& Randall, R.J. (1951) Protein measurements with the Folin phenol reagent. F. biol. Chem. 193, 265-275.

LunN, S.F. \& Lorraine, J.A. (1973) The effect of initial age on the response of the rat to treatment gonadotrophins. Acta endocr., Copenh. 72, 209-217.

Pharriss, B. (1971) Prostaglandin induction of luteolysis. Ann. N. X. Acad. Sci. 180, 436-444.

QuatTropani, S.L. \& WEIsz, J. (1973) Conversion of progesterone to estrone and estradiol in vitro by the ovary of the infantile rat in relation to the development of its interstitial tissue. Endocrinology 92, $1269-1276$.

Siddall, A.C. (1928) A suggested test for pregnancy. F. Am. med. Ass. 90, 380.

Somjen, D., Kaye, A.M. \& Lindner, H.R. (1973) Postnatal development of uterine response to estradiol-17 $\beta$ in the rat. Devl Biol. 31, 409-412.

Sterling, K. (1960) Radioactive chromium technic for circulating red cell volume. Meth. med. Res. $8,69-75$.

SzEGo, C.M. \& GrTtN, E.S. (1964) Ovarian histamine depletion during acute hyperaemic response to luteinizing hormone. Nature, Lond. 201, 682-684.

Tsafriri, A., Lindner, H.A., Zor, U. \& Lamprecht, S.A. (1972) Physiological role of prostaglandins in the induction of ovulation. Prostaglandins 2, 1-10.

TUKEY, J.W. (1949) Comparing individual means in the analysis of variance. Biometrics 5, 99-114.

Uma Bai, R., Bisghoff, K., Macome, J.C. \& Diczfalusy, E. (1973) In vitro sterol and steroid synthesis by ovaries of hypophysectomized immature rats treated with human gonadotrophins. Acta endocr., Copenh. 73, 321-334.

VANE, J. (1971) Inhibition of prostaglandin synthesis as a mechanism of action for aspirin like drugs. Nature, New Biol. 231, 232-235. 
Villee, C.A., Channing, C., Eckstein, B. \& Sulovid, V. (1969) Effects of gonadotrophins on the metabolism of luteinized and follicular ovarian tissues. In The Gonads, pp. 277-294. Ed. K. W. McKerns. North-Holland Publishing Co., Amsterdam.

Weeks, J.R. (1972) Prostaglandins. A. Rev. Pharmac. 12, 317-336.

Weisz, J. \& Gunsalus, P. (1973) Estrogen levels in immature female rats: true or spurious-ovarian or adrenal? Endocrinology 93, 1057-1065.

ZoNDEk, B. (1926) Ueber die funktion des ovariums. Dt. med. Wschr. 8, 343-344.

Zondek, B. \& Aschieim, S. (1927) Hypophysenvorderlappenhormon und ovarium. Beziehungen der endokrinen Drusen zur Ovarial funktion. Arch. Gynäk. 130, 1-45.

Zondek, B. \& Sulman, F. (1945) The mechanism of action and metabolism of gonadotropic hormones in the organism. Vitams Horm. 3, 297-336.

Zondek, B., Sulman, F. \& Black, R. (1945) The hyperemia effect of gonadotropins on the ovary. $\mathcal{F}$. Am. med. Ass. 128, 939-944.

Zor, U., Bauminger, S., Lamprecht, S.A., Kogh, Y., Ghobsieng, P. \& Lindner, H.R. (1973) Stimulation of cyclic AMP production in the rat ovary by luteinizing hormone: independence of prostaglandins mediation. Prostaglandins 4, 499-507. 